\title{
Geology of the Precambrian mafic-ultramafic Näränkävaara intrusion - Review of recent results
}

\author{
V. Järvinen* and J. S. Heinonen \\ University of Helsinki \\ *Corresponding author e-mail: ville.jarvinen@helsinki.fi
}

\begin{abstract}
Summary The Precambrian Näränkävaara intrusion comprises a $1.3 \mathrm{~km}$ thick layered series (dated at $2436 \mathrm{Ma}$ ), and a 1.5-2 km thick 'basal dunite' series (not dated). The layered series contains an ultramafic zone (harzburgite-websterite) and a mafic zone (gabbronorite-diorite) with typical igneous layering, and two reversals back to peridotitic compositions caused by influx of less-fractionated mafic magma. The basal dunite is dominated by low-porosity olivine adcumulates, and exhibits open-system lithological features (e.g., bimodal olivine, poikilitic chromite, and varying Mg\#'s with height); it is also compositionally layered. Contact relationships between the two series are ambiguous, but Sm-Nd systematics strongly suggest a comagmatic origin $\left(\varepsilon_{\mathrm{Nd}}\right.$ from -1.7 to -3.5 at $\left.2.44 \mathrm{Ga}\right)$. Furthermore, estimated parental magma compositions for both series are similar and represent LREE-enriched high$\mathrm{Mg}$ basalts with 13-18 wt $\% \mathrm{MgO}$. The layered series hosts an uneconomic 20-85 m thick offset-type PGE-reef with $\mathrm{Pd}+\mathrm{Pt}+\mathrm{Au}$ of $50-500 \mathrm{ppb}$ and $\mathrm{Pd} / \mathrm{Pt}$ of $\sim 3$. The basal dunite series exhibits varying Nicontents at a similar $\mathrm{Mg} \#$ - the Ni-depletion in some sections could hypothetically be caused by Ssaturation, however any significant sulfides have not been found in the basal dunite series. Petrogenetically, it is hypothesized that the basal dunite represents an earlier part of magmatism with slightly higher $\mathrm{MgO}$ and Ni parental magma, and possibly (at least partly) an open system feeder channel environment, which then evolved into a more static magma chamber environment forming the layered series.
\end{abstract}

\section{Introduction and background to current research}

Several mafic layered intrusions were emplaced in the NE Fennoscandian shield during longlived mantle plume magmatism at 2.5-2.4 Ga, with many of these intrusions hosting Ni-CuPGE mineralization (Bayanova et al. 2009). Parental magmas of these intrusions can be classified as komatiitic or High-Mg basalts contaminated with Archean crust (average $\varepsilon_{\mathrm{Nd}}$ approximately $-2, \mathrm{MgO} 9-18 \mathrm{wt} \%$; Kulikov et al. 2010). The Näränkävaara intrusion is the easternmost member of the Tonio-Näränväkaara belt of intrusions, which have an average age of 2.44 Ga. Näränkävaara is included in the Koillismaa-Näränkävaara Layered Intrusion Complex (KLIC), comprising the Western Intrusions of the Koillismaa Complex in the west, and Näränkävaara intrusion in the east, with the two connected by a large-scale geophysical anomaly dubbed the 'hidden dyke' (see map in Fig. 1) speculated to represent a feeder channel (Alapieti 1982).

The Näränkävaara intrusion (Fig. 1) comprises 1) a layered series (dated at $2436 \mathrm{Ma}$; Alapieti 1982), and 2) a basal dunite series (not dated). The $1300 \mathrm{~m}$ thick layered series is almost unaltered and contains an ultramafic zone composed of peridotites-pyroxenites and a mafic zone composed of gabbronorite-quartz diorite. Typical magmatic layering is found in both series with cumulus-phases appearing in order olivine+chromite-orthopyroxeneclinopyroxene-plagioclase-magnetite; two reversals back to peridotitic compositions are found, one in each zone, with both related to influxes of new relatively unfractionated magma. An uneconomic 20-85 m thick offset-type PGE-reef ("SL reef") with 50-500 ppb of $\mathrm{Pd}+\mathrm{Pt}+\mathrm{Au}$ and an average $\mathrm{Pd} / \mathrm{Pt}$ of 3 of is found at the border of the ultramafic and mafic 

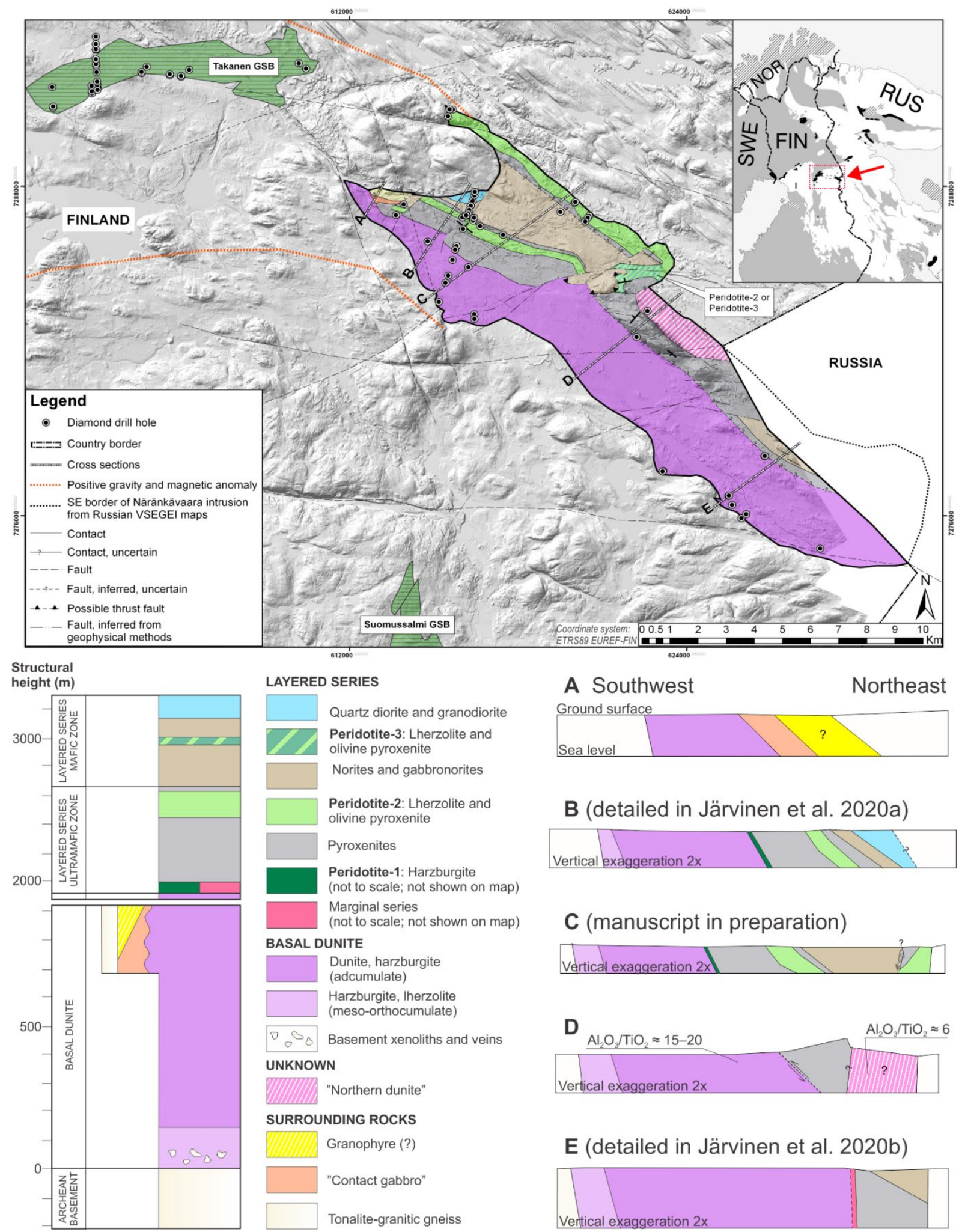

A Southwest

Northeast

Ground surface

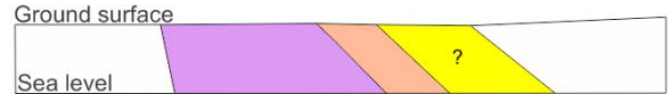

B (detailed in Järvinen et al. 2020a)

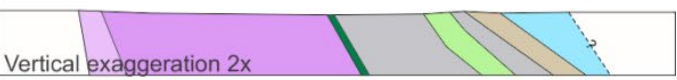

C (manuscript in preparation)
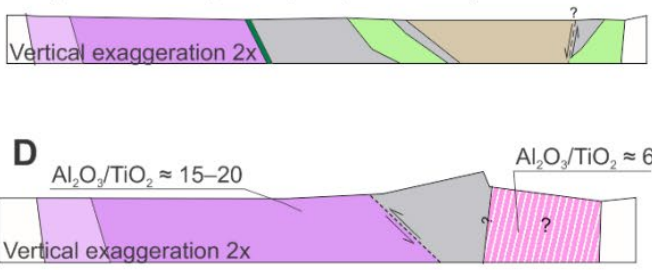

E (detailed in Järvinen et al. 2020b)

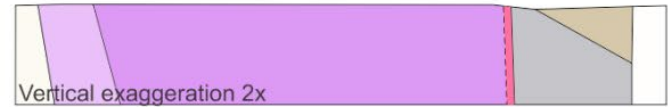

Figure 11. Simplified geological map, magmatic stratigraphy, and relevant cross-sections of the Precambrian mafic-ultramafic Näränkävaara intrusion. Map overlain on hill-shaded topography. Inset shows 2.5-2.4 Ga mafic intrusions in Fennoscandia (black) with Näränkävaara and KLIC pointed out. 
zones - apparently the reef began to form before the first lithological reversal but reef-formation was halted by the influx of new magma, and resumed soon after disappearance of olivine from the liquidus (Järvinen et al 2020a). The $\sim 1500-2000$ m thick basal dunite series is thoroughly serpentinized and dominated by low-porosity olivine adcumulates with minor orthocumulates and (ortho)pyroxenites. Whole-rock geochemistry can be used to separate the body into 10 subzones (layers) with Mg\#'s decreasing from south to north towards the layered series (Fig. 1), however with several reversals to more primitive compositions (Järvinen et al. 2020b).

In addition, a $\sim 20 \mathrm{~m}$ thick marginal series gabbronorite separates these two series (in the SE-block of the intrusion, see Fig. 1), grading into pyroxenites of the layered series and with a tectonic contact to the basal dunite. The current location of the marginal series suggests a hiatus in magmatism between the two series, but it may also be the result of post-magmatic faulting.

\section{Research questions at hand}

This is a 4-year $\mathrm{PhD}$ project in which we aim to update the geology, petrogenesis, and $\mathrm{Ni}-\mathrm{Cu}-$ Co-PGE mineral potential of the Näränkävaara intrusion, based on the wealth of new sample materials that have become available since the last major study (Alapieti 1982).

The primary interest is related to the origin and Ni-criticality of the basal dunite series. It exhibits several lithological features typically described from open-system komatiitic cumulates, e.g. abundance of 'extreme' olivine adcumulates, back-and-forth variation in Mg\# with stratigraphic height, bimodal olivine, and poikilitic chromite. Among other things, this led to the hypothesis that the basal dunite might in-fact represent an Archean komatiitic wall-rock to the Paleoproterozoic layered series magmatism. However, two major results contradict this hypothesis, and rather argue for a $\sim 2.44 \mathrm{Ga}$ related intrusive origin. First, the parental magmas of both series were determined by 1) direct analysis of the marginal series, 2) weighted average calculation of the layered series, and 3) modelled from the southern margin olivine orthocumulate of the basal dunite (inferred to represent olivine-melt mixes) (Järvinen et al. 2020a \& 2020b) - all three parental magmas show similar LREE-enriched high-MgO basaltic compositions with 13-18 wt\% MgO (Fig. 2A), similar to other 2.5-2.4 Ga intrusions. Second, whole-rock Sm-Nd isotope systematics of both series are compatible with a crustally contaminated Paleoproterozoic plume origin (Fig. 2B), and similar to other intrusions of the same age ( $\varepsilon N d-1.7--3.5$ at $2.44 \mathrm{Ga}$; Järvinen et al. 2021). We speculate that the basal dunite represents an earlier part of KLIC magmatism with a slightly higher $\mathrm{MgO}$ parental magma (15$18 \mathrm{wt} \%$ ), and possibly (at least partly) an open system feeder channel environment; evolving into a more static magma chamber environment forming the layered series, with two late influxes of relatively unfractionated magma of similar composition (13-15 $\mathrm{wt} \% \mathrm{MgO}$ ).

A distinct Ni-depletion is found in the basal dunite, both in whole-rock analyses with varying Ni at a similar Mg\# (Fig. 3C), and in mineral analyses of chromite and olivine (3200$2150 \mathrm{ppm} \mathrm{Ni}$ in olivine at Fo87.5). It is possible that this depletion is related to sulfide saturation depleting the residual magma in $\mathrm{Ni}$, and as such the basal dunite is thought to have potential for internal or marginal/offset Ni-sulfide mineralization.

The layered series hosts an uneconomic PGE-reef which is homogeneous along a strike length of $5 \mathrm{~km}$. It is unlikely that this reef would contain significantly higher quantities of PGE along undrilled profiles. However, all parental magma determinations show "fertile" magma compositions in that the magmas contain close to primitive mantle quantities of $\mathrm{Ni}-\mathrm{Cu}-\mathrm{PGE}$, and as such there is potential for e.g. marginal sulfide deposits. 

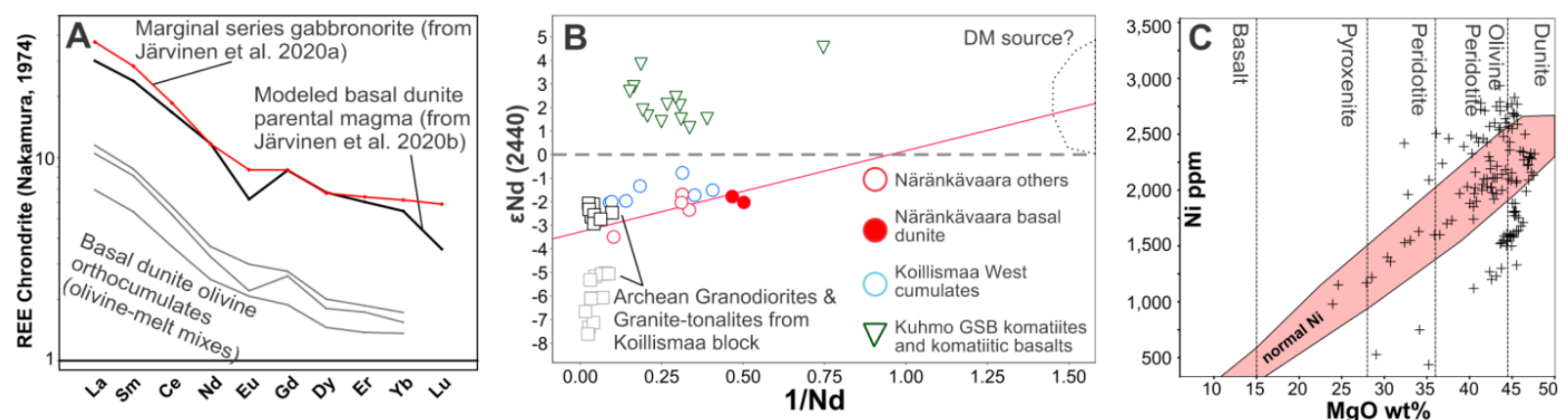

Figure 2. Whole-rock geochemical diagrams from the Näränkävaara intrusion A REE-diagram comparing parental magma compositions of the layered series and the basal dunite $\mathbf{B} \varepsilon_{\mathrm{Nd}} \mathrm{vs} 1 / \mathrm{Nd}$ diagram illustrating comagmatic plume-related origin of layered series and basal dunite (mix of depleted mantle plume source(?) and Archean crustal contaminant) $\mathbf{C ~ N i ~ v s . ~} \mathrm{MgO}$ diagram of basal dunite olivine cumulates illustrating Ni-depletion (variable $\mathrm{Ni}$ at similar $\mathrm{MgO}$ ).

\section{Future prospects}

The geological framework of the KLIC is still poorly known: we speculate that the basal dunite is at least partly a feeder channel cumulate, having fed the layered intrusion(s), and is possibly related to the 'hidden dyke' previously speculated to represent a feeder channel as well (Alapieti 1982).

The possibility of Ni-sulfide saturation in the basal dunite warrants further investigation by, e.g., low-detection limit whole-rock PGE analyses and in-situ chromite trace-element analyses to investigate possible PGE-depletion that could have been caused by sulfide saturation. The 'hidden dyke' also forms an interesting target for Ni-Cu-PGE sulfide exploration, as it overlaps with a small Archean greenstone belt with abundant volcanosedimentary sulfides which could have provided a sulfur-rich wall-rock contaminant for the Paleoproterozoic magmas.

Another open question is the formation process of extrusive komatiite-like cumulus textures in intrusive systems - especially of the poikilitic chromite which is generally only described from primitive high-temperature high-volume komatiite flows (Godel et al. 2013).

\section{References:}

Alapieti TT (1982) The Koillismaa layered igneous complex, Finland -its structure, mineralogy and geochemistry, with particular emphasis on distribution of chromium. Geol Surv Fin Bull 319:1-116

Bayanova T, Ludden J, Mitrofanov F (2009) Timing and duration of Palaeoproterozoic events producing orebearing layered intrusions of the Baltic Shield: metallogenic, petrological and geodynamic implications. In: Reddy S. et al (eds) Palaeoproterozoic Supercontinents and Global Evolution. Geol Soc London Spec Pub 323:165-198. doi: 10.1144/SP323.8

Godel B, Barnes SJ, Gürer D et al (2013) Chromite in komatiites: 3D morphologies with implications for crystallization mechanisms. Contrib Mineral Petrol 165:173-189, doi: 10.1007/s00410-012-0804-y

Järvinen V, Halkoaho T, Konnunaho J et al (2020a) Parental magma, magmatic stratigraphy, and reef-type PGE enrichment of the 2.44 Ga mafic-ultramafic Näränkävaara layered intrusion, northern Finland. Miner Depos 55:1535-1560, doi: 10.1007/s00126-019-00934-z

Järvinen V, Halkoaho T, Konnunaho J et al (2020b) The basal dunite of the Precambrian mafic-ultramafic Näränkävaara intrusion: Petrogenetic considerations and implications to exploration. Miner Petrol 115:3761. doi:10.1007/s00710-020-00725-9

Järvinen V, Halkoaho T, Konnunaho J et al (2021) Sm-Nd isotope systematics of the Precambrian mafic-ultramafic Näränkävaara intrusion. LITHOSPHERE 2021 Symposium Programme and Extended Abstracts, Jan 1920.

Kulikov VS, Bychkova YV, Kulikova VV et al (2010) The Vetreny Poyas (Windy Belt) subprovince of southeastern Fennoscandia: An essential component of the ca. 2.5-2.4 Ga Sumian large igneous province. Precam Res 183(3):589-601, doi:10.1016/j.precamres.2010.07.011 